\title{
RESPONS PETERNAK TERHADAP PEMANFAATAN PAKAN DEDAK PADI FERMENTASI UNTUK PERTAMBAHAN BOBOT AYAM KAMPUNG UNGGUL BALITBANGTAN (KUB) FASE GROWER
}

\section{The Farmers Response to The Use of Fermented Rice Bran Feed for Weight Gaining of Kampung Unggul Balitbangtan (KUB) Chicken Grower Phase}

\author{
P. Tandi Balla, Medi, Muh. Irfan Aryawiguna, dan Munawir Badaruddin \\ Politeknik Pembangunan Pertanian (Polbangtan) Gowa \\ Jl Malino km 7. Romanglompoa, Kecamatan Bontomarannu, Kabupatan Gowa Provinsi Sulawesi Selatan, 92171 Gowa \\ e-mail: medi.dama98@gmail.com
}

Received: 22 Agustus 2020; Accepted: 7 Mei 2021; Published: 25 Juni 2021

\begin{abstract}
ABSTRAK
Tujuan dari pelaksanaan penelitian ini adalah untuk mengetahui pemanfaatan pakan dedak padi fermentasi terhadap pertambahan bobot badan harian, konversi ransum dan konsumsi ransum ayam Kampung Unggul Balitbangtan (KUB) fase grower. serta mengetahui respons peternak terhadap teknologi tersebut. Penelitian dilaksanakan menggunakan Rancangan Acak Lengkap (RAL) dengan 4 perlakuan dan 5 ulangan. Hasil penelitian menunjukkan bahwa pemanfaatan dedak padi fermentasi sebanyak $30 \%$ dalam ransum dapat meningkatkan pertambahan bobot badan harian, konversi ransum dan konsumsi ransum. Pelaksanaan penyuluhan terkait hasil penelitian cukup efektif dalam meningkatkan pengetahuan, keterampilan dan perubahan sikap responden dengan nilai efektivitas penyuluhan sebesar 35,18\%, yang berarti berada pada kriteria cukup efektif.
\end{abstract}

Kata kunci: Peternak, dedak padi, ayam KUB

\section{ABSTRACT}

This study aims to examine the effect of the utilization of fermented rice bran on daily weight gaining, ration conversion, and the consumption of the kampung chicken Unggul Balitbangtan (KUB) phase Grower. It also aims to identify the response of farmers towards the materials. The research design was a completely randomized design with four treatments by five repetitions. The result analysis showed that adding $30 \%$ of fermented rice bran significantly affected daily weight gaining, ration conversion, and consumption. The advisory session was moderately effective in improving the knowledge, skill, and attitude of farmers with a score of 35,18 .

Keywords: Farmers, rice bran, KUB chicken

\section{PENDAHULUAN}

Ayam kampung atau yang lebih dikenal dengan ayam buras merupakan ternak unggas yang mengalami perubahan populasi dalam 5 tahun terakhir. Menurut data Kementerian Pertanian (2019), populasi ayam buras dalam 5 tahun terakhir secara berturut-turut yaitu 26.065.905 ekor pada tahun 2015, kemudian 29.243.017 ekor pada tahun $2016(+13,18 \%)$, kemudian mengalami penurunan hingga 29.063.682 ekor pada tahun 2017 (-0,61\%), kemudian mengalami peningkatan 30.807.676 ekor tahun $2018(+6,0 \%)$ dan kembali mengalami peningkatan 32.941.255 ekor pada tahun 2019 $(+6,92 \%)$. Populasi ayam buras di Provinsi Sulawesi Selatan pada tahun 2019 sebesar 10,56 \%

Diterbitkan Oleh,

Unit Penelitian dan Pengabdian Masyarakat, Politeknik Pembangunan Pertanian Gowa

http://ejournal.polbangtan-gowa.ac.id 
dari total populasi ayam buras nasional dengan jumlah 32.942.255 ekor menjadikan Provinsi Sulawesi Selatan sebagai salah satu provinsi dengan populasi ayam buras terbesar di Indonesia. Ayam buras memiliki beberapa jenis yang dibudidayakan masyarakat Indonesia, salah satunya adalah Ayam KUB.

Sari (2017) mengemukakan bahwa Ayam KUB merupakan jenis ayam kampung dengan gallur baru yang dihasilkan dan dikembangkan Badan Litbang Pertanian. Pengembangan dan pertambahan populasi ayam KUB seiring dengan peningkatan kebutuhan pakan ayam KUB. Ditinjau dari segi ekonomi pakan merupakan aspek penting dalam budidaya ayam KUB. Menurut Syahrir (2007), Produksi dan produktivitas ternak junga sangat di pengaruhi oleh pakan sebagai salah satu faktor utama, namun dilain pihak biaya pakan menempati proporsi terbesar dari total biaya produksi yaitu 70-80\%. Dengan demikian, salah satu faktor penentu efisiensi usaha budidaya ayam KUB adalah penggunaan pakan yang murah, mudah diperoleh dan berkualitas.

Dedak padi merupakan salah satu bahan pakan yang paling penting dalam ransum ayam KUB. Menurut Ichwan (2003), penggunaan dedak padi dalam pakan ternak unggas memang dibatasi karena kandungan serat kasarnya relatif tinggi sekitar $12 \%$, tetapi karena ketersediaannya cukup melimpah dan harganya relatif murah maka bahan pakan ini sebaiknya digunakan. Serat kasar yang relatif tinggi menjadi salah satu faktor pembatas penggunaan dedak padi dalam formulasi ransum ungags, maka dibutuhkan suatu upaya untuk mengatasi hal tersebut.

Berdasarkan hasil identifikasi potensi wilayah di Kecamatan Turikale, Kabupaten Maros, Provinsi Sulawesi Selatan, populasi ayam KUB di Kecamatan Turikale terdapat sebanyak 1500 ekor dengan populasi ayam KUB terbesar berada di Kelurahan Pattuadae sebanyak 1000 ekor (66.66\%) dari total populasi ayam KUB di Kecamatan Turikale.

Ketersediaan dedak padi yang melimpah di Kelurahan Pattuadae membuat petani padi yang juga sebagai peternak ayam KUB menggunakan dedak padi sebagai pakan ternak ayam KUB. Peningkatan nilai gizi dedak padi dan peningkatan kecernaan melalui proses fermentasi merupakan hal penting untuk dilaksanakan. Berdasarkan kondisi tersebut, maka penulis tertarik untuk melakukan pengkajian mengenai respons peternak terhadap pemanfaatan pakan dedak padi fermentasi untuk pertambahan bobot ayam kampung unggul balitbangtan KUB fase grower.

\section{METODE PENELITIAN}

\section{Tempat dan Waktu}

Pelaksanaan kajian materi dilaksanakan di Instalasi Ternak Unggas Kampus Polbangtan Gowa yang pada bulan Maret sampai bulan Mei 2020. Selanjutnya pelaksanaan penyuluhan dilaksanakan di kelompok tani Sejatera Baru, Kelurahan Pattuadae, Kecamatan Turikale, Kabupaten Maros, Provinsi Sulawesi Selatan pada bulan Juni 2020.

\section{Alat dan Bahan}

Alat yang dibutuhkan dalam pengkajian ini adalah kandang, tempat makan dan minum unggas komersil, timbangan, petak percobaan, drum, terpal, sekop, alat tulis menulis, Benner serta peralatan dokumentasi. Bahan yang dibutuhkan adalah ayam KUB fase grower, EM4, molases, dedak padi, tepung jagung dan konsentratMetode Pelaksanaan Kajian

Rancangan pengkajian menggunakan Rancangan Acak Lengkap (RAL) dengan 4 perlakuan dan 5 ulangan serta menggunakan 3 ayam KUB per petakan berukuran $0,5 \mathrm{~m}^{2}$ dengan perlakuan sebagai berikut :

$\mathrm{P} 0=$ Ransum basal, dedak biasa $30 \%$

$\mathrm{P} 1=$ Subtitusi dedak fermentasi $10 \%$

P2 $=$ Subtitusi dedak fermentasi $20 \%$

P3= Subtitusi dedak fermentasi $30 \%$

\section{Populasi dan Sampel}

Populasi yang digunakan dalam pelaksanaan kajian adalah ayam Kampung Unggul Balitbangtan (KUB) sebanyak 60 ekor dengan berat rata-rata 652 gram/ekor, dan sampel yang digunakan adalah ayam kampung unggul balitbangtan (KUB) fase grower berumur 2 bulan yang berada dalam petak percobaan. Teknik penarikan sampel yang digunakan adalah teknik sensus untuk meningkatkan akurasi data. 
Responden penyuluhan adalah Kelompok Tani Sejatera Baru, kelurahan Paattuadae, Kecamatan Turike, Kabupaten Maros, Provinsi Sulawesi Selatan.

\section{Teknik Pengumpulan Data}

\section{Konsumsi ransum}

Pengukuran konsumsi ransum dilakukan dalam waktu 24 jam setelah pemberian ransum. Konsumsi ransum dihitung menggunakan rumus (Triyastuti, 2005) :

$$
K \cdot \text { Ransum }=\frac{(\text { Ransum Diberikan }- \text { Sisa })}{\text { Waktu }}
$$

\section{Konversi pakan}

Konversi pakan diperoleh dengan cara membagi jumlah ransum yang dikonsumsi dengan pertambahan bobot badan selama pemeliharaan. Konversi ransum dapat diperoleh dengan rumus (Triyastuti, 2005):

$$
\text { Konversi }=\frac{\text { Konsumsi Pakan }}{\text { Pertambahan Bobot Badan }}
$$

\section{Pertambahan bobot badan}

Pertambahan bobot badan (PBB) diperoleh dengan membagi jumlah kenaikan bobot badan dan waktu pemeliharaan. Pertambahan bobot badan diperoleh dengan rumus (Triyastuti, 2005):

$$
P B B=\frac{(B B \text { Akhir }-B B \text { Awal })}{\text { Waktu }}
$$

\section{Respons Peternak}

Data mengenai respons peternak (pengetahuan, sikap dan pengetahuan) diperoleh dari nilai kuesioner yang diberikan sebelum dan sesudah penyuluhan.

\section{Analisis Data}

Data dari hasil pengukuran selanjutnya di analisis menggunakan analisis of varian (ANOVA) dengan menggunakan SPSS versi 25 dan perlakuan yang berbeda akan dilakukan uji lanjutan menggunakan Duncan's Multiple Range Test (DMRT).

\section{Pelaksanaan Penyuluhan}

Penyuluhan dilaksanakan di Kecamatan Turikale, Kabupaten Maros. Target wilayah pelaksanaan penyuluhan adalah Kelompok Tani Sejatera Baru, yang terletak di Kelurahan Pattuadae, kecamatan Turikale. Penyuluhan diawali dengan pengucapan salam dan kata pengantar kemudian dilanjutkan dengan pemaparan materi menggunakan metode ceramah. Setelah pemaparan materi menggunakan metode ceramah, dilanjutkan dengan pelaksanaan demonstrasi cara dan hasil serta diskusi. Setelah diskusi dilaksanakan, kemudian dilanjutkan dengan pembagian folder dan penutup.

\section{Evaluasi Penyuluhan}

Teknik yang dilakukan dalam pengumpulan data yaitu dengan mengajukan pertanyaan (kuisioner) sebagai alat ukur yang terdiri dari 15 pertanyaan dan masing-masing aspek, terdiri dari 5 pertanyaan dengan 4 kriteria. Hasil penilaian tes awal dan tes akhir diberi skor dengan ketentuan sebagai berikut: jawaban (a) nilai 4, jawaban (b) nilai 3, jawaban (c) nilai 2 dan jawaban (d) nilai 1. Kuesioner terlebih dahulu diuji menggunakan uji validasi dengan rumus korelasi Product Moment (Singarimbun dan Effendi, 1989):

$$
=\frac{\left(\mathbf{N} \times \sum \mathbf{X Y}\right)-\left(\sum \mathbf{X} \times \sum \mathbf{Y}\right)}{\sqrt{\left[\mathbf{N}-\left(\sum \mathbf{X}\right)^{2}\right]\left[\mathbf{N} \times \mathbf{Y}^{2}-(\mathbf{Y})^{2}\right]}}
$$

Keterangan :

$r \quad=$ Nilai validitas kuesioner

$\mathrm{N}=$ Jumlah responden

$\sum \mathrm{X}=$ Skor kuesioner ke $-\mathrm{i}$

$\sum X^{2}=$ Kuadrat skor kuesioner ke $-\mathrm{i}$

$\sum Y=$ Skor total dari semua kuesioner

$\sum Y^{2}=$ Kuadrat skor dari semua kuesioner

$\sum \mathrm{XY}=$ Skor pertanyaan ke $-\mathrm{i}$ dikali skor total dari semua kuesioner

Setelah diuji validitasnya, Metode yang digunakan untuk mengetahui tingkat pengetahuan, keterampilan dan sikap responden yaitu dengan menggunakan rating scale atau skala nilai kemudian diolah dan ditabulasi dengan menggunakan garis kontinum.(Padmowihardjo, 2002). 
DOI: 10.52625/j-agr-sosekpenyuluhan.v17i1.180

$$
\text { Peningkatan Aspek }=\frac{\text { Jumlah Skor }}{\text { Nilai Tertinggi }} \times 100 \%
$$

Untuk mengetahui efektivitas penyuluhan digunakan kriteria persentase efektivitas dengan menggunakan rumus sebagai berikut :

$$
\mathrm{EP}=\frac{\mathrm{Ps}-\mathrm{Pr}}{\mathrm{N} 4 \mathrm{Q}-\mathrm{Pr}} \times 100 \%
$$

Keterangan :

Ps $\quad=$ Post test

Pr $=$ Pree test

$\mathrm{N} \quad=$ Jumlah responden

$4=$ Nilai tertinggi

$\mathrm{Q}=$ Jumlah pertanyaan

$100 \%=$ Pengetahuan yang ingin dicapai

Ps-Pr = Peningkatan pengetahuan

$\mathrm{N} 4 \mathrm{Q}-\mathrm{Pr}=$ Nilai kesenjangan
Maka nilai persentase efektifitas tingkat pengetahuan adalah, $<32 \%=$ Kurang efektif; $32-$ $64 \%=$ Cukup efektif; $>64 \%=$ Efektif

\section{HASIL DAN PEMBAHASAN}

\section{Pertambahan Bobot Badan}

Rata-rata pertambahan bobot badan ayam KUB fase grower selama pengkajian diolah dengan menggunakan uji Analisis of Varians. Data Analisis of varians menunjukan bahwa penambahan dedak padi fermentasi dalam ransum terhadap pertambahan bobot badan harian ayam KUB fase grower berpengaru nyata karena nilai signifikan lebih kecil dari nilai taraf 0,05 (5\%). Data tersebut kemudian diuji lanjutan dengan menggunakan Duncan's Multiple Rage Test (DMRT).

Tabel 1. Rata-rata pertambahan bobot badan ayam KUB fase grower (gram/ekor/hari)

\begin{tabular}{cc}
\hline Perlakuan & Rata-rata \\
\hline P0 & $44^{\mathrm{a}}$ \\
P1 & $47^{\mathrm{ab}}$ \\
P2 & $50^{\mathrm{b}}$ \\
P3 & $59^{\mathrm{c}}$ \\
\hline KK $(\%)$ & 2,70 \\
\hline
\end{tabular}

abc Superskrip berbeda pada kolom yang sama menunjukkan perbedaan nyata $(\mathrm{P}<0.05)$

Data dari Tabel 1 menunjukkan bahwa rata-rata pertambahan bobot badan harian ayam KUB dalam pelaksanaan kajian diperoleh hasil perlakuan P3 memiliki pertambahan bobot badan harian tertinggi adalah sebesar 59 gram/ekor/hari, kemudian P2 sebesar 50 gram/ekor/hari, P1 sebesar 47 gram/ekor/hari dan terendah P0 sebesar 44 gram/ekor/hari.

Pertambahan bobot badan dipengaruhi oleh konsumsi ransum dan kandungan protein ransum. Anggorodi dalam Zurmiati $d k k$ (2017) menyatakan bahwa konsumsi pakan ternak mempengaruhi pertambahan berat badan ternak. Pesti dalam Zurmiati $d k k$ (2017) menyatakan bahwa kandungan protein menjadi tolak ukur pertumbuhan dan efisiensi pakan.

Ali $d k k$ (2019), juga menam bahkan bahwa pemberian dedak padi fermentasi dalam ransum menghasilkan pertambahan bobot badan yang lebih tinggi, hal ini disebabkan karena kualitas pakan semakin baik setelah difermentasi. Untuk mencapai pertambahan bobot badan yang optimal sesua dengan potensi genetik ternak diperlukan ransum yang mengandung unsur gizi secara kualitatif dan kuantitatif, dengan demikin kecepatan pertumbuhan berhubungan dengan konsumsi ransum.

\section{Konversi Ransum}

Rata-rata konversi ransum ayam KUB fase grower selama pengkajian diolah dengan menggunakan uji Analisis Of Varians. Data Analisis of varians menunjukan bahwa penambahan dedak padi fermentasi dalam ransum terhadap konversi ransum ayam KUB fase grower berpengaru nyata karena nilai signifikan lebih kecil dari nilai taraf 0,05 (5\%). Data tersebut kemudian diuji lanjutan dengan menggunakan Duncan Test.

Diterbitkan Oleh, 
DOI: $10.52625 /$ j-agr-sosekpenyuluhan.v17i1.180

Tabel 2. Rata-rata konversi ransum ayam KUB fase grower

\begin{tabular}{cc}
\hline Perlakuan & Rata-rata \\
\hline P0 & $3,96^{\mathrm{c}}$ \\
P1 & $3,72^{\mathrm{bc}}$ \\
P2 & $3,48^{\mathrm{b}}$ \\
P3 & $3,08^{\mathrm{a}}$ \\
\hline KK $(\%)$ & 0,64 \\
\hline abc
\end{tabular}

${ }^{\text {abc }}$ Superskrip berbeda pada kolom yang sama menunjukkan perbedaan nyata $(\mathrm{P}<0.05)$

Data dari Tabel 2 menunjukkan bahwa rata-rata konversi ransum ayam KUB dalam pelaksanaan kajian diperoleh hasil perlakuan P3 memiliki nilai konversi ransum terenda adalah sebesar 3,08, kemudian P2 sebesar 3,48, P1 sebesar 3,72 dan yang tertinggi adalah P0 sebesar 3,96.

Berdasarkan hasil kajian yang telah dilakukan dengan penggunaan suptitusi dedak padi fermentasi dalam ransum berpengaruh nyata terhadap konversi ransum ayam KUB fase grower. Menurut Lacy dan Vest dalam Fahrudin $d k k$ (2017), beberapa faktor yang mempengaruhi konversi ransum adalah perkandangan, genetik, kualitas ransum, penyakit, temperatur, sanitasi kandang, ventilasi, pengobatan dan manajemen kandang. Selain itu, faktor pemberian ransum, penerangan, laju perjalanan ransum dalam saluran pencernaan, bentuk fisik ransum dan komposisi nutrisi ransum juga ikut mempengaruhi nilai konversi ransum.

\section{Konsumsi Ransum}

Rata-rata konsumsi ransum ayam KUB fase grower selama pengkajian diolah dengan menggunakan uji Analisis of Varians. Data Analisis of varians menunjukan bahwa penambahan dedak padi fermentasi dalam ransum terhadap kosusmsi ransum ayam KUB fase grower berpengaru nyata karena nilai signifikan lebih kecil dari nilai taraf 0,05 (5\%). Data tersebut kemudian diuji lanjutan dengan menggunakan Duncan's Multiple Rage Test (DMRT).

Tabel 3. Rata-rata konsumsi ransum ayam KUB fase grower

\begin{tabular}{cc}
\hline Perlakuan & Rata-rata \\
\hline P0 & $5100^{\mathrm{a}}$ \\
P1 & $5237^{\mathrm{b}}$ \\
P2 & $5247^{\mathrm{b}}$ \\
P3 & $5317^{\mathrm{b}}$ \\
\hline KK $(\%)$ & 5,39 \\
\hline
\end{tabular}

${ }^{\mathrm{ab}}$ Superskrip berbeda pada kolom yang sama menunjukkan perbedaan nyata $(\mathrm{P}<0.05)$

Data Tabel 3 menunjukkan bahwa rata-rata konsumsi ransum ayam KUB dalam pelaksanaan kajian diperoleh hasil perlakuan P3 memiliki nilai konsumsi ransum tertinggi adalah sebesar 5317 gram, kemudian P2 sebesar 5247 gram, P1 sebesar 5237 gram dan nilai terenda adalah P0 sebesar 5100 gram

Berdasarkan hasil kajian yang telah dilakukan dengan suptitusi dedak padi fermentasi dalam ransum berpengaruh nyata terhadap konsumsi ransum ayam KUB fase grower. Tingginya konsumsi ransum P3 disebabkan oleh rendahnya serat kasar ransum. Serat kasar ransum berfungsi untuk memberikan rasa kenyang bagi ternak, semakin tinggi serat kasar ransum maka semakin rendah konsumsi ransum. Menurut Rasyaf (2005) konsumsi ransum dipengaruhi oleh kebutuhan energi dan kadar energi ransum. Kadar energi dalam ransum dapat memenuhi kebutuhan pokok maka ransum yang dikonsumsi lebih sedikit. 


\section{Evaluasi Penyuluhan dan Respons Peternak Ayam KUB}

Evaluasi penyuluhan (Tabel 4) terdiri dari evaluasi awal dan evaluasi akhir yang dilakukan dengan menggunakan rating scale kemudian ditabulasi dan diolah menggunakan garis continuum.

Efektivitas penyuluhan terkait ketiga aspek penyuluhan secara keseluruhan mencapai $35,18 \%$ atau cukup efektif. Jika ditinjau lebih seksama maka ditemukan bahwa terdapat 2 instrumen pada aspek sikap yang masih berada pada wilayah raguragu, yakni penerapan teknologi fermentasi dedak padi dalam lingkup usaha tani dan dampak baik dedak padi fermentasi pada lingkup usaha tani. Kedua instrumen tersebut berkaitan dengan keyakinan peternak ayam KUB untuk menggunakan dedak padi fermentasi bagi usaha tani mereka. Menurut Umstot dalam Indreswari, dkk (2014), kebutuhan akan memotivasi seseorang untuk berperilaku ke arah pemenuhan kebutuhan tersebut. Berkaitan dengan hal tersebut maka ke depannya perlu dibagas lebih dalam analisa ekonomi dari penggunaan dedak padi fermentasi terhadap usaha tani guna menggugah sikap responden.

Tabel 4. Hasil Evaluasi Pelaksanaan Penyuluhan

\begin{tabular}{ccccccc}
\hline \multirow{2}{*}{ Aspek Penyuluhan } & \multicolumn{3}{c}{ Nilai yang diperoleh } & \multicolumn{3}{c}{ Perubahan } \\
\cline { 2 - 7 } & Pre-Test & $(\%)$ & Post-Test & $(\%)$ & Skor & $(\%)$ \\
\hline Pengetahuan & 229 & 45,8 & 348 & 69,6 & 119 & 23,8 \\
Keterampilan & 210 & 42 & 320 & 64 & 110 & 22 \\
Sikap & 215 & 43 & 290 & 58 & 75 & 15 \\
\hline Total & 654 & 43,6 & 958 & 63,86 & 304 & 20,26 \\
Rerata & 218 & 43,6 & 319,33 & 63,86 & 101,33 & 20,26 \\
\hline
\end{tabular}

Efektivitas Penyuluhan $35,18 \%$

\section{KESIMPULAN}

1. Berdasarkan hasil pengkajian yang telah dilaksanakan, Penambahan dedak padi fermentasi sebanyak 30\% memberikan hasil terbaik pada pertambahan berat badan harian, konsumsi ransum dan konversi ransum, ayam KUB Fase Grower

2. Respons peternak terhadap pemamfaatan pakan dedak padi fermentasi untuk pertambahan bobot badan ayam KUB fase grower, terjadi peningkata pada aspek pengetahuan sebesar 23,8\%, aspek keterampilan mengalami peningkatan sebesar $22,00 \%$ dan aspek sikap mengalami perubahan sebesar $15 \%$ dengan efektivitas penyuluhan sebesar $35,18 \%$, yang berarti berada pada kriteria cukup efektif.

\section{DAFTAR PUSTAKA}

Ali, N., Agustintina., Dahniar. 2019 Pemberian Dedak Padi Yang Difermentasi Dengan Em4 Sebagai Pakan Ayam Broiler [pdf]. Jurnal Ilmu Pertanian Volume 4. Nomor 1, mei 2019. Tersedis Di http://dx.doi.org/10.35329/agrovital.v4il.2 98. Diakses 15 maret 2020

Fahrudin A., Tanwiriah W. dan Indrijani H. 2017. Konsumsi Ransum, Pertambahan Bobot Badan dan Konversi Ransum Ayam Lokal di Jimmy's Farm Cipanas Kabupaten Cianjur. [Pdf]. Tersedia di https://www.researchjournal.co.in//. (Online). Diakses 22 Juni 2020.

Ichwan, W. M. 2003. Membuat Pakan Ayam Ras Pedaging. Cetakan ke -1 . PT. Agromedia Pustaka. Jakarta 
Indreswari. R, Ratriyanto. A dan Dewanti. R. 2014. Evaluasi Penyuluhan Pemeliharaan Itik Lokal Jantan Berbasis Metode Inditik Terhadap Tingkat Pengetahuan dan Sikap Petani di Desa Gaum Kecamatan Tasikmadu Kabupaten Karanganyar. [Pdf]. Tersedia di https://core.ac.uk>download $>$ pdf//. (Online). Diakses 30 Juni 2020.

Kementerian Pertanian. 2019. Populasi Ayam Buras Menurut Provinsi. Direktorat Jendral Peternakan Dan Kesehatan Hewan.[Pdf]. Tersedia di http://ww.pertanian.go.id//. (Online). Diakses 8 Maret 2020.

Padmowihardjo. 2002. Metode Penyuluhan Pertanian. Universitas Terbuka. Jakarta.

Rasyaf, M. 2005. Beternak Ayam Petelur.Penebar swadaya. Jakarta

Sari, L.M. Tantato, S.Nova, K. 2017. Performa Ayam KUB (Kampung Unggul Balitnak) Periode Grower Pada Pembrian Ransum Dengan Kadar Protein Kasar Yang Berbeda. [pdf]. Jurnal Riset Dan Inovasi Peternakan Vol.1(3):36-41. Th2017.
Tersedia di http://scolar. Google.com. (Online). Diakses pada 1 juni 2020.

Singarimbun dan Effendi. 1989. Metode Pengkajian Survai. Cetakan pertama. PT. Midas Surya Grafindo. Jakarta.

Syahrir, S. 2007. Suptitusi Jagung Dengan Gaba Dalam Ransum Broiler Fase finiser. Buletin Nutrisi dan Makanan Ternak. Vol. 6(1). Fakultas Peternakan Universitas Hasanudin. Makassar.

Triyastuti, A. 2005. Pengaruh Penambahan Enzym Dalam Ransum Terhadap Performan Ayam kampung unggul balitbangtan (KUB) Jantan. [Pdf]. Tersedia di https://core.ac.uk>download $>$ pdf//. (Online). Diakses 17 maret 2020

Zurmiati, Wizna, Abbas. M. H. dan Mahata. M. E. 2017. Pengaruh Imbangan Energi dan Protein Ransum Terhadap Pertumbuhan Itik Pitalah Yang Diberi Probiotik Bacillus amyloliquefaciens. [Pdf]. Tersedia di https://core. ac.uk>download>pdf//. (Online). Diakses 30 Juni 2020. 